\title{
Establishment of Leguminous Trees in the Soil of a Shooting Range
}

\author{
Rafael Nogueira Scoriza ${ }^{1}$ (D), Maria Elizabeth Fernandes Correia ${ }^{2}$ (C) \\ ${ }^{1}$ Universidade Federal Rural do Rio de Janeiro (UFRRJ), Seropédica, RJ, Brasil \\ ${ }^{2}$ Centro Nacional de Pesquisa de Agrobiologia da Empresa Brasileira de Pesquisa Agropecuária (Embrapa), \\ Seropédica, RJ, Brasil
}

\begin{abstract}
Shooting range activities risk contaminating the soil, posing potential risks to human health, the local biota, and water sources. Considering that soil organisms are the first to be affected by contamination, this study aimed to evaluate the initial growth of the leguminous tree Albizia polycephala and its association with microbes in soil taken from this area. The collected soil was placed in 60-ml tubes with legume seeds and stored in a greenhouse for 60 days. The differences in the legumes' growth were not related to the physical and chemical properties of the soil, nor to its metal content, but rather to mycorrhizal colonization and nodulation, which were shown to be effective in creating favorable conditions. This indicates that the site under study has great natural potential for the establishment of tree species, which could be impaired if it continues to be used for shooting practice.
\end{abstract}

Keywords: soil contamination, restoration, protected area, Albizia polycephala. 


\section{INTRODUCTION AND OBJECTIVES}

As one of Brazil's environmentally protected areas, the National Forest's main roles include contributing to the maintenance of biological diversity and genetic resources, environmental preservation, and the restoration of diversity (Brazil, 2000). Some activities that take place in environmentally protected areas may conflict with these goals. In the Ipanema National Forest, in the state of São Paulo, Brazil, an active shooting range has been installed in a former limestone quarry designated for natural restoration.

Shooting range activities risk contaminating the area with lead, the metal that forms the main component of bullets. This contamination poses potential risks to human health, the local biota, and water sources. Other contaminants such as arsenic and antimony may also be present in the bullets. The main factors that determine the levels of metals found in the soil of the shooting ranges are frequency of use, type of ammunition, soil properties, and local climate (Sorvari et al., 2006; Ahmad et al., 2012.). At the same time, mining activities, in addition to devastating parts of the landscape, have an enormous impact on ecosystems, including loss of biodiversity in all its forms and increased concentration of barium in the surrounding soil and water (Suwa et al., 2008; Chaer et al., 2011).

Lead ranks second on the list of priority toxic substances of the U.S. Environmental Protection Agency (Usepa, 2004). This metal is persistent in the environment and tends to increase with the bullets' rate of degradation, which is determined primarily by the properties of local soils (Sorvari et al., 2006; Selonen \& Setela, 2015). Organisms in the soil are the first to be affected by lead contamination, which in turn affects the diversity and structure of the microbe and plant community, the food chain, ecological functions, and the physiological and biochemical processes that are vital to photosynthesis and the metabolism of nitrogen (Singh et al., 1997; Rantalainen et al., 2006; Xu et al., 2012; Souza et al., 2012a; Selonen \& Setela, 2015).

Barium, an alkaline metal, has no known biological function, but can cause serious harm to most organisms (Llugany et al., 2000; Suwa et al., 2008; Lamb et al., 2013) despite being immobile in the soil, (Pichtel et al., 2000) where it naturally occurs. The few plants that can be established in barium-contaminated areas, such as mines, usually contain high concentrations of barium, which can affect their productivity and this metal's movement up the food chain and through the ecosystem (Llugany et al., 2000; Lamb et al., 2013).

To determine appropriate uses for a site where these activities are present in the context of a National Forest's conservation, studies are required to assess the types of contaminants, their concentrations, their effects on soil organisms, and ultimately strategies to promote reforestation. The success of such intervention depends primarily on the successful restoration of nutrient cycling and the selection of plant species (Chaer et al., 2011; Rao \& Tak, 2002).

Some species of leguminous trees are able to germinate and grow in soils with high concentrations of contaminants such as lead (Souza et al., 2012b). Albizia polycephala (Benth.) Killip ex Record is a native species with potential for this purpose. It is a climax species with anemochory-type dispersal that requires light, occupying the forest canopy in rainforests and seasonal forests. In addition, it is associated with bacteria of the genus Rhizobium, producing abundant nodules (Carvalho, 2006). Interactions with microorganisms, such as rhizobia and mycorrhizal fungi, protect the plant from contaminants and promote its growth by increasing the absorption of nutrients by the roots and fixing nitrogen from the air into degraded soils. Moreover, the mycorrhizal fungi can promote phytostabilization and immobilization of heavy metals (Ban et al., 2015; Chaer et al., 2011; Lin et al., 2007; Ma et al., 2006; Souza et al., 2012a; Xu et al., 2012). This symbiosis has been effective in limestone quarrying areas (Rao \& Tak, 2002).

Therefore, the presence of a shooting range in a quarry can lead to contamination by lead and barium that might already be present in the area. These factors, either independently or in combination, can set back natural regeneration or reforestation activities in this area because they may be toxic to plants and symbiotic microorganisms. This study aimed to evaluate the initial growth of the leguminous tree Albizia polycephala and its association with soil microbes in the study area.

\section{MATERIALS AND METHODS}

The Ipanema National Forest covers more than 5,000 ha in the Southeastern region of the state of 
São Paulo, Brazil, encompassing the municipalities of Iperó, Araçoiaba da Serra and Capela do Alto (Ibama, 2003), in a semideciduous seasonal forest region. An active shooting range has been installed in a quarry located at $23^{\circ} 25^{\prime} \mathrm{S} / 47^{\circ} 38^{\prime} \mathrm{W}$, at an average elevation of $650 \mathrm{~m}$. The quarry was probably installed at this site to maintain a safe distance from the most frequently visited areas of the National Forest, as well as to minimize noise pollution (Ahmad et al., 2012). The area can be accessed through a passage between two steep slopes (carved on the outer part of the hillside), covered by grass, shrubs, and trees. Inside the pit, soil is scarce or non-existent, originated by the deposition of residues of the highest parts of the land, with areas of exposed rock and sparse vegetation. Some areas are flooded because of a ravine on the west side that allows soil and moisture to accumulate, resulting in the presence of some medium-sized trees. The east side is a valley occupied by tall, thick grass, especially Melinis minutiflora and Panicum maximum, as well as several trees.

Limestone quarrying began in 1951 to supply a local cement factory and wound down between 1999 and 2001. The shooting range was established between 2008 and 2009, initially as a training and practice range for state employees. In addition to target practice, the pit now serves as a site for training with non-lethal weapons such as tear gas, pepper spray, and other equipment.

Soil sampling was carried out in August 2015 and limited to the area affected by the shooting range, in a non-flooded section of land. Sampling was performed along two transects starting from the backstop, with points marked in five-meter intervals (Figure 1). A perpendicular line was drawn at each point, and four simple soil samples were collected in one-meter intervals, at a depth of $0-10 \mathrm{~cm}$. The material was placed in labeled plastic bags and taken to the laboratory.

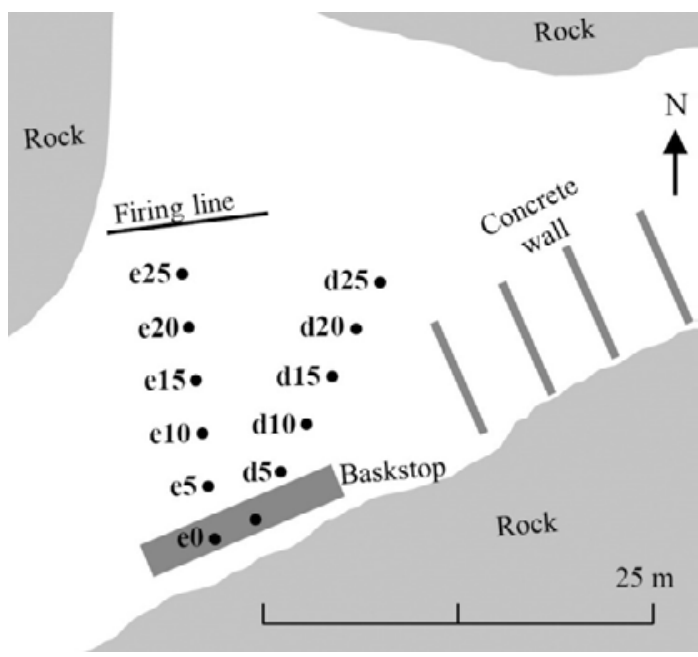

Figure 1. Distribution of the soil sample points at the shooting range in the former limestone quarry of the Ipanema National Forest, SP.

The soil was air-dried for $48 \mathrm{~h}$ in the laboratory and then sieved through a $4 \mathrm{~mm}$ mesh. The presence of a large amount of rock chips and a small amount of finely ground material made the use of this mesh necessary. After this, the sub-samples were combined to form a composite sample for each point.

In order to assess their physical and chemical properties and test for the presence of heavy metals, the soil samples were sieved through a $2 \mathrm{~mm}$ mesh, and measurements were taken for $\mathrm{pH}\left(\mathrm{H}_{2} \mathrm{O}\right)$, concentration of macronutrients $(\mathrm{N}=$ Kjedahl; $\mathrm{Ca}$ and $\mathrm{Mg}=$ absorption atomic spectroscopy; $\mathrm{K}=$ flame photometry; $\mathrm{P}=$ colorimetric analysis) and organic carbon (Walkey \& Black) (Nogueira \& Souza, 2005), texture (total dispersion) (Embrapa, 2011), and total presence of heavy metals, like barium, lead, copper, chromium, nickel and zinc (Standard Methods, 1999). Table 1 shows only the metals that had values higher than the level at which investigation is recommended (Cetesb, 2014).

Table 1. Physical and chemical characteristics and heavy metal concentrations in soil samples taken from the shooting range in the old quarry of the Ipanema National Forest, SP.

\begin{tabular}{lccccccccccc} 
Point & e0 & e5 & e10 & e15 & e20 & e25 & d5 & d10 & d15 & d20 & d25 \\
Carbon $\left(\mathrm{g} \mathrm{kg}^{-1}\right)$ & 0.32 & 0.29 & 0.33 & 0.5 & 1.33 & 0.78 & 0.48 & 0.52 & 0.39 & 0.83 & 1.26 \\
Nitrogen $\left(\mathrm{g} \mathrm{kg}^{-1}\right)$ & 0.03 & 0.05 & 0.05 & 0.06 & 0.14 & 0.11 & 0.07 & 0.07 & 0.06 & 0.09 & 0.13 \\
Calcium $\left(\mathrm{cmolc} \mathrm{d}^{-3}\right)$ & 1.74 & 1.42 & 8.68 & 9.44 & 11.14 & 12.11 & 5.03 & 6.21 & 9.87 & 9.82 & 8.74 \\
Magnesium $\left(\mathrm{cmolc} \mathrm{d}^{-3}\right)$ & 1.02 & 2.86 & 9.1 & 8.91 & 5.4 & 5.23 & 6.24 & 6.43 & 8.88 & 8.78 & 8.34 \\
\hline
\end{tabular}


Table 1. Continued...

\begin{tabular}{lccccccccccc} 
Point & e0 & e5 & e10 & e15 & e20 & e25 & d5 & d10 & d15 & d20 & d25 \\
\hline Potassium $\left(\mathrm{mg} \mathrm{L}^{-1}\right)$ & 85.72 & 77.07 & 126.58 & 144.91 & 128.37 & 91.36 & 136.27 & 125.78 & 127.54 & 154.14 & 158.09 \\
\hline Phosphorus $\left(\mathrm{mg} \mathrm{L}^{-1}\right)$ & 2.55 & 11.41 & 66.97 & 56.81 & 70.49 & 55.67 & 63.26 & 73.74 & 57.62 & 73.47 & 88.9 \\
\hline $\mathrm{pH}(\mathrm{KCl} \mathrm{lM})$ & 5.01 & 6.98 & 7.1 & 7.13 & 7.72 & 7.89 & 7.22 & 7.53 & 7.41 & 7.43 & 7.39 \\
\hline Fine sand $\left(\mathrm{g} \mathrm{kg}^{-1}\right)$ & 27.7 & 7.1 & 8.8 & 10.1 & 11.4 & 13.8 & 5.6 & 6.2 & 3.3 & 10.7 & 8.8 \\
\hline Coarse sand $\left(\mathrm{g} \mathrm{kg}^{-1}\right)$ & 7.4 & 7.9 & 41.7 & 34.7 & 34.8 & 37.5 & 27.6 & 16.3 & 9.9 & 38.6 & 36.7 \\
Sand $\left(\mathrm{g} \mathrm{kg}^{-1}\right)$ & 35.1 & 15.0 & 50.5 & 44.8 & 46.2 & 51.3 & 33.2 & 22.5 & 13.2 & 49.3 & 45.5 \\
\hline Clay $\left(\mathrm{g} \mathrm{kg}^{-1}\right)$ & 28.9 & 19.3 & 21.7 & 20.6 & 16.2 & 12.2 & 24.4 & 18.7 & 21.5 & 19.9 & 20.9 \\
\hline Silt $\left(\mathrm{g} \mathrm{kg}^{-1}\right)$ & 36.0 & 65.7 & 27.8 & 34.6 & 37.6 & 36.5 & 42.4 & 58.8 & 65.3 & 30.8 & 33.6 \\
\hline Barium $\left(\mathrm{mg} \mathrm{kg}^{-1}\right)$ & 16.3 & 66.1 & $298,8^{*}$ & $226,2^{*}$ & $266,8^{*}$ & $305,5^{*}$ & $187,7^{*}$ & $346,4^{*}$ & $330,2^{*}$ & $241,9^{*}$ & $173,5^{*}$ \\
Lead $\left(\mathrm{mg} \mathrm{kg}^{-1}\right)$ & & & & & & & & & $674,3^{* *}$ & \\
\hline
\end{tabular}

${ }^{\star}$ Higher than prevention levels; ${ }^{*}$ Higher than investigation levels. Cestesb (2014).

Commercially purchased seeds of Albizia polycephala were immersed in a $2 \%$ sodium hypochlorite solution for three minutes to disinfect their surfaces. Then, they were scraped using sandpaper (\#100) to facilitate the absorption of water by the seed. Ten hard plastic $60 \mathrm{ml}$ tubes containing soil that had been sieved through a 4-mm mesh were used to store two seeds each. The first seedling to grow a pair of leaves was kept in the tube, while the other was cut off at its base. The experiment was conducted in a non-sterile greenhouse at an average temperature of $25^{\circ} \mathrm{C}$ and approximately $60 \%$ humidity, in entirely random blocks, with ten repetitions for 60 days. Soil irrigation occurred twice a week

After germination, measurements of the plants' height (using a ruler in centimeters) and its diameter at the base of the stem (using a digital caliper in millimeters) were taken every two weeks. At the end of the experiment, the dry weight of the plant's aerial part (g), the dry weight of the root $(\mathrm{g})$, the dry weight of its nodules $(\mathrm{g})$, and the root colonization rate (\%) were obtained. To measure the root colonization rate, the roots were first rinsed in running water, and then a random $0.5 \mathrm{~g}$ sample of fine roots was taken from each sample. After each sample was placed in its own test tube, it was subjected to the following treatments: soaked in $2.5 \%$ potassium hydroxide for 24 hours, then rinsed in running water, then soaked in $1 \%$ hydrochloric acid for 24 hours, and then soaked in $0.05 \%$ methyl blue dye in acidified glycerol for 24 hours. The percentage of fungal structures on the root was measured using the grid line intersect method, whereby the samples were

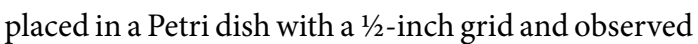

under a stereo microscope (Newman, 1966; Philips \& Hayman, 1970; Giovannetti \& Mosse, 1980; Koske \& Gemma, 1989; Grace \& Stribley, 1991).

Data were subjected to Levene's test for the homogeneity of variance and to the Kolmogorov-Smirnov test for normality. The Scott-Knott and Friedman tests were used to assess parametric and nonparametric data, and correlation coefficients were obtained using the Pearson and Spearman (method) test, respectively, at $5 \%$ significance. To minimize the effect of differences due to soil properties (Table 1) and focus on the effects caused by contaminants, the points were divided into groups based on their Principal Components Analysis (Leps \& Smilauer, 2003) using the data on the physical and chemical characteristics of the soil (except for contaminants).

\section{RESULTS}

The initial growth of the legume Albizia polycephala showed no significant correlation with the physical and chemical properties or with the barium content of the soil in which it was planted. The unitary lead data did not allow the correlation analysis. However, some correlations between the symbiotic microorganisms, the soil, and the plant were detected. Mycorrhizal colonization was significantly correlated with macronutrients $\mathrm{Ca}$ $(\mathrm{r}=-0.75)$ and $\mathrm{P}(\mathrm{r}=-0.60), \mathrm{pH}(\mathrm{r}=-0.80)$, percentage of clay $(r=0.85)$, and barium concentration $(r=-0.82)$. The nodules' weight was significantly correlated with some of the legume's growth parameters, such as the diameter at the base of the stem $(r=0.74)$ and the weight of the aerial part of the plant $(r=0.87)$. 
The principal component analysis divided the sampling points on the shooting range into two groups, with $75.3 \%$ of the variance explained: $52.8 \%$ by the $\mathrm{x}$-axis and $22.5 \%$ by the $\mathrm{y}$-axis. Group 1 was formed of soil samples with similar silt content, consisting of points e5, d5, d10 and d15. Group 2 included samples with similar content of fine and coarse sand, consisting of points e10, e15, e20, e25, d20 and d25. Point $\mathrm{e} 0$ showed a stronger association with the clay and fine sand content, being isolated from the other points (Figure 2). For this reason, a comparison will be drawn between the two primary groups of points with respect to the growth parameters of the plants and their symbionts.

Over the course of the experiment, no differences were observed in the stem diameter of the plants grown in different soil samples. A height difference was observed after 45 days, when the seedlings growing in soil sampled from points e10, e15, and e25 were taller than those growing in soil sampled from the other two points in that group (Table 2).

At the end of the experiment, the dry weight of the aerial parts and roots showed differences between the sampled points. In group 1, the aerial parts of the seedlings grown in soil sampled from point $\mathrm{d} 15$

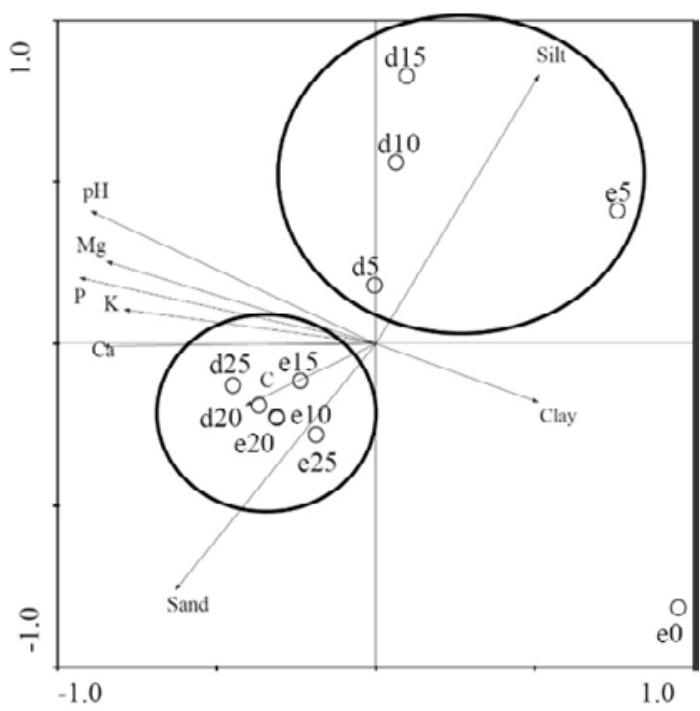

Figure 2. Principal component analysis using the physical and chemical characteristics of the soil (except for contaminants) at the shooting range in the former limestone quarry of the Ipanema National Forest, SP. $\mathrm{C}=$ carbon; $\mathrm{N}=$ nitrogen $\mathrm{Ca}=$ calcium $; \mathrm{Mg}=$ magnesium; $\mathrm{K}=$ potassium, $\mathrm{P}=$ phosphorous.

were heavier. In group 2, the aerial parts and roots of the seedlings planted in soil sampled from points e10, e15, and e25 outweighed the others (Figure 3).

Table 2. Diameter and height of Albizia polycephala seedlings planted in soil taken from different sample points at the shooting range in the former limestone quarry of the Ipanema National Forest, SP.

\begin{tabular}{|c|c|c|c|c|c|c|c|c|}
\hline \multirow[b]{2}{*}{ Point } & \multicolumn{4}{|c|}{ Diameter (mm) } & \multicolumn{4}{|c|}{ Height (cm) } \\
\hline & 15 & 30 & 45 & 60 & 15 & 30 & 45 & 60 \\
\hline & \multicolumn{4}{|c|}{ Days } & \multicolumn{4}{|c|}{ Days } \\
\hline \multicolumn{9}{|c|}{ Group 1} \\
\hline e5 & $1.37 \mathrm{a}$ & $1.45 \mathrm{a}$ & $1.61 \mathrm{a}$ & $1.91 \mathrm{a}$ & $4.7 \mathrm{a}$ & $5.5 \mathrm{a}$ & $5.9 \mathrm{a}$ & $6.2 \mathrm{a}$ \\
\hline d5 & $1.38 \mathrm{a}$ & $1.51 \mathrm{a}$ & $1.79 \mathrm{a}$ & $2.03 \mathrm{a}$ & $5.6 \mathrm{a}$ & $6.4 \mathrm{a}$ & $6.6 \mathrm{a}$ & $6.7 \mathrm{a}$ \\
\hline $\mathrm{d} 10$ & $1.43 \mathrm{a}$ & $1.58 \mathrm{a}$ & $1.68 \mathrm{a}$ & $1.94 \mathrm{a}$ & $5.9 \mathrm{a}$ & $6.7 \mathrm{a}$ & $7.1 \mathrm{a}$ & $7.3 \mathrm{a}$ \\
\hline $\mathrm{d} 15$ & $1.56 \mathrm{a}$ & $1.57 \mathrm{a}$ & $1.78 \mathrm{a}$ & $2.15 \mathrm{a}$ & $5.1 \mathrm{a}$ & $5.9 \mathrm{a}$ & $6.5 a$ & $6.8 \mathrm{a}$ \\
\hline \multicolumn{9}{|c|}{ Group 2} \\
\hline e10 & $1.52 \mathrm{a}$ & $1.75 \mathrm{a}$ & $1.94 \mathrm{a}$ & $2.31 \mathrm{a}$ & $5.7 \mathrm{a}$ & $6.8 \mathrm{a}$ & $7.7 \mathrm{a}$ & $8.4 \mathrm{a}$ \\
\hline e15 & $1.54 \mathrm{a}$ & $1.61 \mathrm{a}$ & $1.92 \mathrm{a}$ & $2.27 \mathrm{a}$ & $6.0 \mathrm{a}$ & $7.4 \mathrm{a}$ & $7.8 \mathrm{a}$ & $8.5 \mathrm{a}$ \\
\hline $\mathrm{e} 20$ & $1.54 \mathrm{a}$ & $1.58 \mathrm{a}$ & $1.70 \mathrm{a}$ & $1.94 \mathrm{a}$ & $5.5 \mathrm{a}$ & $6.1 \mathrm{a}$ & $6.6 \mathrm{~b}$ & $7.2 b$ \\
\hline e25 & $1.62 \mathrm{a}$ & $1.72 \mathrm{a}$ & $1.93 a$ & $2.21 \mathrm{a}$ & $5.9 \mathrm{a}$ & $6.6 a$ & $7.3 \mathrm{a}$ & $8.0 \mathrm{a}$ \\
\hline $\mathrm{d} 20$ & $1.47 \mathrm{a}$ & $1.55 \mathrm{a}$ & $1.78 \mathrm{a}$ & $2.06 \mathrm{a}$ & $5.3 \mathrm{a}$ & $6.2 \mathrm{a}$ & $6.3 \mathrm{~b}$ & $6.6 \mathrm{~b}$ \\
\hline d25 & $1.35 \mathrm{a}$ & $1.47 \mathrm{a}$ & $1.55 \mathrm{a}$ & $1.84 \mathrm{a}$ & $5.6 \mathrm{a}$ & $6.0 \mathrm{a}$ & $6.4 \mathrm{~b}$ & $6.7 \mathrm{~b}$ \\
\hline
\end{tabular}

Lower-case versions of the same letter denote no significant difference by the Friedman and Scott-Knott tests for height and diameter, respectively, at $5 \%$ significance. 


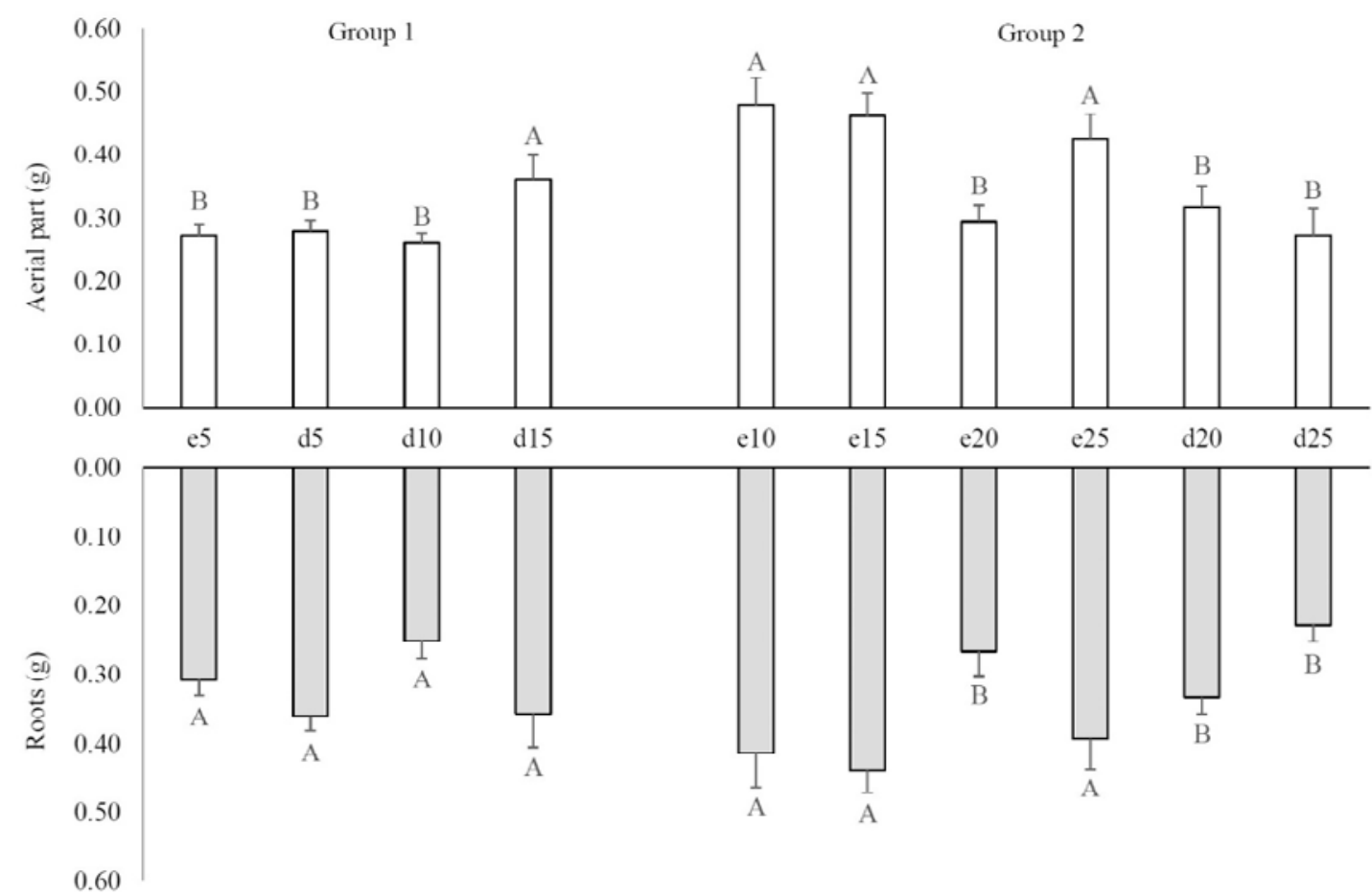

Figure 3. Weight of the dry aerial parts and roots of Albizia polycephala seedlings grown in soil taken from different sample points at the shooting range in the former limestone quarry of the Ipanema National Forest, SP.

With respect to the naturally occurring symbiotic soil microbes associated with Albizia polycephala, the percentage of mycorrhizal colonization in the seedlings' roots did not differ between sample points. The weight of the nodules showed differences within Group 1, with the plants grown in soil sampled from point e5 having shown smaller nodules than those grown in soil sampled from points $\mathrm{d} 10$ and d15 (Table 3).

\section{DISCUSSION}

Only one of the soil sample points at the shooting range located in the limestone quarry (point $\mathrm{d} 15$ ) surpassed the most extreme reference level of lead contamination $\left(150 \mathrm{mg} \mathrm{kg}^{-1}\right.$ for agricultural and rural areas), called "intervention", according to criteria set by the environmental agency of the state of São Paulo (Cetesb, 2014). The barium concentration at several points exceeds only the milder "prevention" level of $120 \mathrm{mg} \mathrm{kg}^{-1}$. However, the "prevention" values are established based on phytotoxicity assays or ecological risk assessment. When the level of a contaminant exceeds
Table 3. Mycorrhizal colonization and dry weight of the nodules of Albizia polycephala seedlings grown in soil from different sample points at the shooting range in the former limestone quarry of the Ipanema National Forest, SP.

\begin{tabular}{ccc} 
Point & Colonization (\%) & Nodules $(\mathrm{g})$ \\
\cline { 2 - 3 } & Group 1 & \\
\hline e5 & $30.0 \mathrm{a}$ & $0.018 \mathrm{~b}$ \\
\hline $\mathrm{d} 5$ & $31.6 \mathrm{a}$ & $0.019 \mathrm{ab}$ \\
$\mathrm{d} 10$ & $19.8 \mathrm{a}$ & $0.024 \mathrm{a}$ \\
$\mathrm{d} 15$ & $25.2 \mathrm{a}$ & $0.044 \mathrm{a}$ \\
\hline & Group 2 & \\
\hline $\mathrm{e} 10$ & $27.1 \mathrm{a}$ & $0.043 \mathrm{a}$ \\
\hline $\mathrm{e} 15$ & $23.0 \mathrm{a}$ & $0.046 \mathrm{a}$ \\
\hline e20 & $24.7 \mathrm{a}$ & $0.028 \mathrm{a}$ \\
\hline e25 & $18.3 \mathrm{a}$ & $0.043 \mathrm{a}$ \\
\hline $\mathrm{d} 20$ & $24.4 \mathrm{a}$ & $0.031 \mathrm{a}$ \\
\hline $\mathrm{d} 25$ & $26.5 \mathrm{a}$ & $0.025 \mathrm{a}$ \\
\hline
\end{tabular}

Lower-case versions of the same letter denote no significant difference by the Friedman and Scott-Knott tests for colonization and nodules, respectively, at $5 \%$ significance. 
its permissible limit, it may harm the soil's ability to carry out its primary functions, such as sustaining the life of animals, plants, and other living organisms, maintaining the nutrient cycle, and degrading and transforming chemicals and organisms (Conama, 2009). Therefore, even though most of the points are not considered to be contaminated by barium, the legume Albizia polycephala qualifies as an organism that is prone to the effects of the metals present in them, and an assessment of its initial growth can generate important information about the soil's functionality in the area.

The absence of any correlation between the legume's growth and the physical properties, chemical properties, or barium concentration in the soil may be due to the influence of symbiotic microorganisms on their growth. This becomes obvious when one considers the significant correlation between nodule weight, stem diameter, and weight of the aerial part of the legume. Plants that are able to accumulate more nitrogen grow better even in contaminated soil (Lin et al., 2007).

The negative correlations between mycorrhizal colonization and calcium and phosphorous macronutrients reflect the role mycorrhizal fungi play in symbiosis, creating favorable growth conditions even in the soil of mines (Ma et al., 2006) and increasing the plants' absorption capacity when nutrients are scarce or when heavy metals may interfere with their absorption and transport (Lin et al., 2007, Souza et al., 2012a.). This association with mycorrhizal fungi can reduce the stress on the plant and its susceptibility to the influence of heavy metals (Muhammad et al., 2008). Increased nutrient absorption associated with mycorrhizal fungi inoculation has already been reported in areas affected by limestone quarrying (Rao \& Tak, 2002).

These results also indicate the presence of active microorganisms in the soil samples taken from the shooting range. Although high concentrations of metals can interfere with mycorrhizal association (Gattai et al., 2011), mycorrhizal fungus propagules never disappear completely, since some species have high tolerance and effective strategies for adapting to these conditions (Yang et al., 2015). Generally, the presence of mycorrhizal colonization favors the development of nodules and the nitrogen-fixing capability of leguminous trees, even in soils affected by mining (Ma et al., 2006; Lin et al, 2007; Souza et al., 2012a), although this study did not find a significant correlation $(\mathrm{r}=-0.52)$.
The fact that the legumes planted in soil from sample points e10, e15, and e25 grew much taller than the others indicates that there were factors in group 2 leading to better development of the plants that were not analyzed in this study, resulting in a lack of a significant correlation (Table 1).

The fact that the aerial parts of the seedlings grown in soil from sample point $\mathrm{d} 15$ were the heaviest was the opposite of what was expected, given that this was the only point where lead and barium contamination was found. Lead-contaminated soils generally result in reduced growth of leguminous trees, even when associated with microorganisms (Le Bourlegat et al., 2007; Muhammad et al., 2008; Souza et al., 2012b), since the plants spend more energy maintaining their tolerance to this metal (Rantalainen et al., 2006) and their photosynthetic pigments are also harmed (Souza et al., 2012b).

These results might be associated with two factors, acting alone or in combination: (1) The symbiotic action of mycorrhizal fungi reduces the amount of lead carried to the leaves, accumulating the metal only in the roots while protecting the aerial parts from damage (Yang et al., 2007; Ban et al., 2015; Yang et al., 2015). Although not an essential metal for plants, lead is actively absorbed by the roots and accumulates in the roots, leaves, and stems (Souza et al., 2012b), making it the main cause of toxicity in the plant (Singh et al., 1997). Lead naturally has limited mobility in plants after its absorption by the roots (Pichtel et al., 2000), and when it is associated with mycorrhizal fungi, it remains more concentrated in the roots, contributing to the plant's tolerance to the metal and additionally benefiting it with nutrition and vigor (Souza et al., 2012b). (2) The species Albizia polycephala does not display the susceptibility to lead contamination observed in other legumes (Gattai et al., 2011). The sensitivity of plants to lead, even at high doses, can vary in accordance with their genetic and physiological features (Singh et al., 1997).

These hypotheses address the absence of negative effects, but not the greater accumulation of dry material. Greater growth, in this case, might be attributed in part to stimulation of the mycorrhizal fungi's function in the absorption of nutrients such as $\mathrm{P}, \mathrm{Ca}$, and $\mathrm{S}$, and the maintenance of high $\mathrm{P} / \mathrm{Pb}, \mathrm{Ca} / \mathrm{Pb}$, and $\mathrm{S} / \mathrm{Pb}$ ratios in the plant's roots (Yang et al., 2008; Souza et al, 2012a.). 
The plants grown in soil collected from points e10, e15, and e25 showed not only greater height, but also greater dry weight of their aerial parts and roots. As stated previously, this result has no relation to the concentration of nutrients and barium in the soil. When soluble, barium is known to be toxic to plants (Lamb et al., 2013), especially because it blocks the leaves' stomata and potassium channels and limits photosynthetic activity (Llugany et al., 2000; Suwa et al., 2008; Melo et al., 2011). However, much of the barium was present in the environment in a less soluble form, thus having few or no direct adverse effects on the plants (Llugany et al., 2000; Pichtel et al., 2000). Differences in both the height and weight of the aerial parts and roots may be related to the complex relationship between plant, nutrients, and symbiotic microbes.

Mycorrhizal colonization and the dry weight of the nodules were not significantly affected by the presence of metals in the soil, in contrast to the results reported by other authors (Lin et al., 2007; Ma et al., 2006; Gohre \& Paszkowski, 2006; Le Bourlegat et al., 2007; Yang et al., 2008; Gattai et al., 2011; Souza et al., 2012a; Souza et al., 2012b). Heavy metal contamination typically inhibits the germination and formation of mycorrhizal spores and reduces the number and efficiency of nitrogen-fixing nodules. This contradicts the only difference found for the symbiotic microorganisms, which was the lower dry weight of the nodules in the soil material sampled from point e5, where there was a lower concentration of barium $\left(66,1 \mathrm{mg} \mathrm{kg}^{-1}\right)$.

\section{CONCLUSIONS}

Under greenhouse conditions, the initial growth of the leguminous tree Albizia polycephala showed differences that could not be explained by contaminants present in the site. This result may be related to the positive influence of symbiotic microbes on the growth of this legume. Even in the presence of heavy metals, the research site has great natural potential for restoration and reforestation due to the presence of symbiotic microorganisms. The continued use of the area as a shooting range may severely damage it, and managers should therefore assess whether this activity constitutes an appropriate use of the nature reserve.

\section{SUBMISSION STATUS}

Received: 25 July, 2017

Accepted: 12 Mar., 2018

\section{CORRESPONDENCE TO}

\section{Rafael Nogueira Scoriza}

Universidade Federal Rural do Rio de Janeiro

(UFRRJ), Rodovia BR-465, km 7, CEP 23891-000, Seropédica,

Rio de Janeiro, RJ, Brasil

e-mail: rafaelscoriza@gmail.com

\section{REFERENCES}

Ahmad M, Lee SS, Moon DH, Yang JH, Ok YS. A review of environmental contamination and remediation strategies for heavy metals at shooting range soils. In: Malik A, Grohmann E, editor. Environmental protection strategies for sustainable development. New York: Springer; 2012. p. 437-451.

Ban Y, Xu Z, Zhang H, Chen H, Tang M. Soil chemistry properties, translocation of heavy metals, and mycorrhizal fungi associated with six plant species growing on leadzinc mine tailings. Annals of Microbiology 2015; 65(1): 503-515. 10.1007/s13213-014-0886-Z

Carvalho PER. Espécies arbóreas brasileiras. Colombo: Embrapa Florestas; 2006.

Companhia Ambiental do Estado de São Paulo (Cetesb). Decisão de diretoria $n^{\circ}$ 045/2014/E/C/I, de 20 de fevereiro de 2014. Diário Oficial do Estado de São Paulo, São Paulo, Caderno Executivo, Seção 1, p. 53.

Chaer GM, Resende AS, Campello EFC, Faria SM, Boddey RM. Nitrogen-fixing legume tree species for the reclamation of severely degraded lands in Brazil. Tree Physiology 2011;31(2): 139-149. 10.1093/treephys/tpq116

Conselho Nacional de Meio Ambiente (Conama). Resolução $n^{\circ} 420$, de 28 de dezembro de 2009. Dispõe sobre critérios e valores orientadores de qualidade do solo quanto à presença de substâncias químicas e estabelece diretrizes para o gerenciamento ambiental de áreas contaminadas por essas substâncias em decorrência de atividades antrópicas. Diário Oficial da República Federativa do Brasil, Brasília, DF [cited 2019 July 3]. Available from: https://bit.ly/2Jl71Ip.

Empresa Brasileira de Pesquisa Agropecuária (Embrapa). Manual de métodos de análise de solos. Rio de Janeiro: Embrapa Solos; 2011.

Gattai GS, Pereira SV, Costa CMC, Lima CEP, Maia LC. Microbial activity, arbuscular mycorrhizal fungi and inoculation of woody plants in lead contaminated soil. 
Brazilian Journal of Microbiology 2011; 42(3): 859-867. 10.1590/S1517-83822011000300004

Giovannetti M, Mosse B. An evaluation of techniques to measure vesicular-arbuscular mycorrhizal infection in roots. The New Phytologist 1980; 84(3): 484-500. 10.1111/ j.1469-8137.1980.tb04556.x

Gohre V, Paszkowski U. Contribution of the arbuscular mycorrhizal symbiosis to heavy metal phytoremediation. Planta 2006; 223(6): 1115-1122. 10.1007/s00425-0060225-0

Grace, C, Stribley DP. A safer procedure for routine staining of vesicular-arbuscular mycorrhizal fungi. Mycological Research 1991; 95(10): 1160-1162. 10.1016/ S0953-7562(09)80005-1

Koske RE, Gemma JN. A modified procedure for staining roots to detect VA mycorrhizas. Mycological Research 1989; 92(4): 486-488. 10.1016/S0953-7562(89)80195-9

Lamb DT, Matanitobua VP, Palanisami T, Megharaj M, Naidu R. Bioavailability of barium to plants and invertebrates in soils contaminated by barite. Environmental Science and Technology 2013; 47(9): 46704676. 10.1021/es302053d

Le Bourlegat JMG, Rossi SC, Chino CE, Schiavinato MA, Lagôa, AMMA. Tolerância de Leucaena leucocephala (Lam.) de Wit. ao metal pesado chumbo. Revista Brasileira de Biociências 2007; 5(s2): 1017-1019.

Leps J, Smilauer P. Multivariate analysis of ecological data using Canoco. Cambridge: Cambridge University Press; 2003.

Lin A, Zhang X, Wong M, Ye Z, Lou L, Wang Y et al. Increase of multi-metal tolerance of three leguminous plants by arbuscular mycorrhizal fungi colonization. Environmental Geochemistry and Health 2007; 29(6): 473-481. 10.1007/s10653-007-9116-y

Llugany M, Poschenrieder C, Barceló, J. Assessment of barium toxicity in bush beans. Archives of Environmental Contamination Toxicology 2000; 39(4): 440-444. 10.1007/ s002440010125

Ma Y, Dickinson NM, Wong MH. Beneficial effects of earthworms and arbuscular mycorrhizal fungi on establishment of leguminous trees on $\mathrm{Pb} / \mathrm{Zn}$ mine tailings. Soil Biology \& Biochemistry 2006; 38(6): 1403-1412. 10.1016/j.soilbio.2005.10.016

Melo LCA, Alleoni LRF, Carvalho G, Azevedo RA. Cadmium-and barium-toxicity effects on growth and antioxidant capacity of soybean (Glycine max L.) plants, grown in two soil types with different physicochemical properties. Journal of Plant Nutrition and Soil Science 2011; 174(5): 847-859. 10.1002/jpln.201000250

Instituto Brasileiro do Meio Ambiente e dos Recursos Naturais Renováveis (Ibama). Plano de manejo da Floresta Nacional de Ipanema. Brasília, DF: Ibama; 2003.

Muhammad S, Iqbal MZ, Mohammad A. Effect of lead and cadmium on germination and seedling growth of
Leucaena leucocephala. Journal of Applied Science and Environmental Management 2008; 12(2): 61-66. 10.4314/ jasem.v12i3.55497

Newman EJ. A method of estimating the total length of root sample. Journal of Applied Ecology 1996; 3(1): 139-145. $10.2307 / 2401670$

Nogueira ARA, Souza GB. Manual de laboratórios: solo, água, nutrição, vegetação, nutrição animal e alimentos. São Carlos: Embrapa Pecuária Sudeste; 2005.

Philips JM, Hayman DS. Improved procedure for clearing roots and staining parasitic and vesicular-arbuscular mycorrhizal fungi for rapid assessment of infection. Transaction of the British Mycological Society 1970; 55(1): 158-161. 10.1016/S0007-1536(70)80110-3

Pichtel J, Kuroiwa K, Sawyerr HT. Distribution of Pb, $\mathrm{Cd}$ and $\mathrm{Ba}$ in soils and plants of two contaminated sites. Environmental Pollution 2000; 110(1): 171-178. 10.1016/ S0269-7491(99)00272-9

Rantalainen, M.; Torkkeli, M.; Strommer, R.; Setala, H. Lead contamination of an old shooting range affecting the local ecosystem - A case study with a holistic approach. Science of the Total Environment 2006; 369(1-3): 99-108. 10.1016/j.scitotenv.2006.05.005

Rao AV, Tak R. Growth of different tree species and their nutrient uptake in limestone mine spoil as influenced by arbuscular mycorrhizal (AM)-fungi in Indian arid zone. Journal of Arid Environments 2002; 51(1): 113-119. 10.1006/jare.2001.0930

Selonen S, Setala H. Soil processes and tree growth as shooting ranges in a boreal forest reflect contamination history and lead induced changes in soil food webs. Science of the Total Environment 2015; 518-519: 320-327. 10.1016/j.scitotenv.2015.03.018

Singh, RP, Tripathi RD, Sinha SK, Maheshwari R, Srivastava HS. Response of higher plants to lead contaminated environment. Chemosphere 1997; 34(11): 2467-2493. 10.1016/S0045-6535(97)00087-8

Sorvari J, Antikainen R, Pyy O. Environmental contamination at Finnish shooting ranges - the scope of the problem and management options. Science of the Total Environment 2006; 366(1): 21-31. 10.1016/ j.scitotenv.2005.12.019

Souza LA, Andrade SAL, Souza SCR, Schiavinato MA. Arbuscular mycorrhiza confer $\mathrm{Pb}$ tolerance in Calopogonium mucunoides. Acta Physiologiae Plantarum 2012a; 34(2): 523-531. 10.1007/s11738-011-0849-y

Souza SCR, Andrade SAL, Souza LA, Schiavinato MA. Lead tolerance and phytoremediation potential of Brazilian leguminous tree species at the seedling stage. Journal of Environmental Management 2012b; 110: 299-307. 10.1016/j.jenvman.2012.06.015

Standard Methods. 3120 metals by plasma emission spectroscopy. Denver: Standard Methods; 1999. 
Suwa R, Jayachandran K, Nguyen NT, Boulenouar A, Fujita K, Saneoka, H. Barium toxicity effects in soybean plants. Archives of Environmental Contamination Toxicology 2008; 55(3): 397-403. 10.1007/s00244-008-9132-7

United States Environmental Protection Agency (Usepa). Framework for inorganic metals risk assessment. Washington, DC: Usepa; 2004.

Xu ZY, Tang M, Chen H, Ban YH, Zhang HH. Microbial community structure in the rhizosphere of Sophora viciifolia grown at a lead and zinc mine of northwest China. Science of the Total Environment 2012; 435-436: 453-464. 10.1016/j.scitotenv.2012.07.029
Yang R, Tang J, Yang Y, Chen X. Invasive and noninvasive plants differ in response to soil heavy metal lead contamination. Botanical Studies 2007; 48: 453-458.

Yang R, Yu G, Tang J, Chen X. Effects of metal lead on growth and mycorrhizae of an invasive plant species (Solidago canadensis L.). Journal of Environmental Sciences 2008; 20(6): 739-744.

Yang Y, Han X, Liang Y, Ghosh A, Chen J, Tang M. The combined effects of arbuscular mycorrhizal fungi (AMF) and lead $(\mathrm{Pb})$ stress on $\mathrm{Pb}$ accumulation, plant growth parameters, photosynthesis, and antioxidant enzymes in Robinia pseudoacacia L. Plos One 2015; 10(12): 1-24. 10.1371/journal.pone.0145726 